\title{
The Factorial-Reflexive Approach to Diagnosing the Executors' and Contractors' Attitude to Achieving the Objectives by Energy Supplying Companies
}

\author{
Aleksandra Kuzior ${ }^{1}\left(\mathbb{D}\right.$, Aleksy Kwilinski ${ }^{2,3, *(\mathbb{D})}$ and Ihor Hroznyi ${ }^{4}$ \\ 1 Department of Applied Social Sciences, Faculty of Organization and Management, Silesian University of \\ Technology, 26-28 Roosevelt St, 41-800 Zabrze, Poland; aleksandra.kuzior@polsl.pl \\ 2 The London Academy of Science and Business, 120 Baker St, London W1U 6TU, UK \\ 3 Department of Marketing, Sumy State University, 2 Rymskogo Street, 40007 Sumy, Ukraine \\ 4 Department of Personnel Management and Marketing, Faculty of Economics, Zaporizhzhya National \\ University, 66 Zhukovsky Street, 69600 Zaporizhzhya, Ukraine; grozny_igor@ukr.net \\ * Correspondence: a.kwilinski@london-asb.co.uk
}

Citation: Kuzior, A.; Kwilinski, A.; Hroznyi, I. The Factorial-Reflexive Approach to Diagnosing the Executors' and Contractors' Attitude to Achieving the Objectives by Energy Supplying Companies. Energies 2021, 14, 2572. https:// doi.org/10.3390/en14092572

Academic Editor: Andrea Triann

Received: 13 March 2021

Accepted: 28 April 2021

Published: 30 April 2021

Publisher's Note: MDPI stays neutral with regard to jurisdictional claims in published maps and institutional affiliations.

Copyright: (c) 2021 by the authors. Licensee MDPI, Basel, Switzerland. This article is an open access article distributed under the terms and conditions of the Creative Commons Attribution (CC BY) license (https:/ / creativecommons.org/licenses/by/ $4.0 /)$.

\begin{abstract}
The article aims to enhance understanding of how relations, behavior and attitude of the executives and contractors to achieving the objectives by energy supplying companies affect the efficiency of the latter's overall development. There is offered a factor-reflexive approach to diagnosing the executives' and contractors' attitude to realizing the tasks of developing the energy supplying companies. This approach includes models to identify and analyze the factors that influenced the change in contractors' behavior based on the combination of expert techniques, correlation and regression analysis and evaluation of the personnel response to organizational, resource and staffing projects development, through accumulating sufficient statistical information based on the enterprise's features, relations and environment. This approach to diagnosing executives' and contractors' response to the implementation of tasks and the resulting changes takes into account the subjective component of their response. Practical implementation of this approach in monitoring the conformity of the development tasks has proven the ability to identify problems from the viewpoint of the task executives.
\end{abstract}

Keywords: reflexivity; factors; diagnostics; behavior; reaction; executives; contractors; task; development; energy supplying company

\section{Introduction}

The new model of energy supplying companies provides for the complete separation of production, transportation and marketing, which allows consumers to receive electricity both directly from producers and from suppliers. Businesses engaged in the commercial distribution and transmission of electricity must ensure equal access to the networks for all organizations interested. The development of energy supplying companies is based on the available interaction between executives and contractors in the process of implementing development tasks under such operating conditions.

The European Union is committed to a fuel-efficient economy and is moving towards a sustainable energy strategy and climate change mitigation through a combination of direct regulation and market entities' support.

Energy service companies (ESCOs) have the necessary know-how to provide 'turnkey' services and solutions that provide significant reductions in energy costs by addressing various market barriers on locally [1].

Energy services have become the mainstay of energy saving measures in most European countries. The EU's total energy services market was estimated at $\$ 2.7$ billion ( $€ 2.4$ billion) in ESCO revenue in 2015 , with a forecast to grow to $\$ 3.1$ billion ( $€ 2.8$ billion) in 2024 at $1.7 \%$ of the annual growth rate [2]. 
Despite significant efforts aimed at promoting the development of the ESCO market, the following restrictive barriers have been identified in ESCO Member States:

- Distrust on the part of the (potential) client,

- Information and awareness,

- Ambiguity in the legislation,

- Markets' dynamics and their size [1].

It is the problems of distrust on the part of the (potential) client, obtaining clear information and awareness of executives and contractors, lack of experience that this article proposes to solve.

This article intends to analyze how relations, behavior and attitude of the executives and contractors to achieving the objectives of energy supplying companies affect the efficiency of the latter's overall development. Since the energy sector is extremely important for the economy of any country, the attitudes and behavior of those involved in its development at the microlevel affect the growth and efficiency of development projects. All economic systems are open and closed to some extent; these systems include reflex subjects that have an ability to act differently [3-5]. Reflexive control is presented as a process of interaction between two interfering cognitive and influencing functions $[6,7]$.

Research [8-10] on choosing effective strategies for financial investment in the smart city is grounded on reflexive influences on the choice. As the analysis of publications [11-17] shows, the scholars do not offer actual recommendations for considering reflexive influences in the search for sustainable strategies relative to financial investment in these areas of human activity. Besides, as recognized by the authors $[13,18]$, there was proposed a model of adaptive properties that require adjustment even if there is a slight strengthening of a reflective component and changing boundary conditions for investors analyzing the smart city attractiveness.

In $[19,20]$, the authors showed that combined together all aspects of cognitive management technologies will contribute to the successful development of enterprises. Building sustainability, the scholars [21-24] offer combinatorial artificial intelligence models and models for evaluating socioeconomic indicators of this development, which serve as a basis for key competencies determined by cognitive technology.

Research management strategic changes in the company based on the concept of Industry 4.0 [25-28] have shown the need to consider non-linear effects, influencing the efficiency of development.

Among the sources of nonlinear effects that affect the efficiency of energy supplying companies, an important place is occupied by reflexive interactions of participants in the development process at different stages: attempts to predict the actions or intentions of executives and contractors in relation to development tasks.

This is necessary in order to optimize their efforts in the context of enterprise development strategy. In turn, these changes affect the situation, causing new reflexive processes. Not only is the net effect of many processes, but also mechanisms can often be known only later; and those qualitative changes aimed at developing the potential through training and structural and institutional changes, especially through reflexive self-regulation. From reflexive self-regulation also follows the thesis of performativity $[29,30]$.

Thus, reflexivity is understood as a bilateral feedback between the decision and the upcoming events as a continuous process of forming individual executives' and contractors' ideas about the situation, developing on this basis the strategy and tactics of their behavior and, thus, further changing situation development. Rennison B.W. emphasized the role of reflexive feedback cycles [8]. Scientific works [31-41] are grounded on the principles of reflexivity. However, reflexivity is closely connected with inaccuracy. All views and theories may be biased, incomplete or both [5].

Reflexive management requires a transition from the situation to the problem space through reflexive perception. Perception must be interpreted in the knowledge as a tool in order to make a right decision. A person who displays all his practice not only looks at the past actions and events, but obviously looks at the emotions, feelings, actions and reactions 
and uses this information to add to their existing knowledge base and to reach a higher level of understanding [42]. Reflective practice makes it possible to obtain such knowledge.

R. Bryant and G. Wilson [43] emphasize a need in "a more reflective approach that seeks to rethink the basic terms of management as a process". This approach was successful in sustainable development projects where participants rated and enjoyed the academic aspects of using the reflective practice throughout. However, the authors noted the problems associated with displacing the "circularity" theory of reflexive practice of "action" stability [44].

A reflective practice is an individual's ability to reflect on one's own actions in order to engage in the process of lifelong learning [45]. According to one definition, it involves "paying critical attention to practical values and theories that inform about everyday actions, exploring practice reflexively. This leads to an understanding of development" [46]. The rationale for reflective practice is that one experience does not necessarily lead to learning; deliberate reflection on experience is essential [47]. In turn, reflective practice cannot have the same value, it is contextually based on a practitioner [48].

A review of the relevant literature was made to identify the factors that influence the behavior and attitudes of executives and contractors to achieving the energy supplying companies' objectives. However, there is insufficient published research that describes approaches to diagnosing and treating the executives' and contractors' behavior while achieving the energy supplying companies' objectives based on reflective influences on them. Together, these attitudes and behaviors are critical to understanding the ways of solving problems related to the enterprises' development. Section 1 of this article discusses the previous research on diagnosing the executives' and contractors' behavior and their attitude to the power supplying companies' problems based on reflexive relations among the system components and enterprise environment.

Section 2 describes the research methodology.

The study results are presented in Section 3, which has two parts and includes evaluation of the contractors' response to development projects and assessment of the personnel response to organizational, resource and staffing projects development, through accumulating sufficient statistical data allowing for the relations and environment of an energy supplying company.

There is overviewed the proposed factor-reflexive approach to diagnosing the executives' and contractors' attitude to achieving the energy supplying companies' objectives.

\section{Materials and Methods}

When the energy supplying companies set up or set indicators, its contractors are informed about the fact and respond accordingly. Basically, targets that an enterprise is trying to achieve are known to contractors at approval of plans and indicators that characterize the related items during achievement. Thus, the analysis and formalization of reflexive relations between the units of the energy supplying company and the components of the environment. Finally, after taking into account the contractors' reflexive reactions to the power supplying company's plans, there can be implemented the generation tasks to achieve the company objectives. These tasks have already taken into account the response of contractors and appropriate amendments and clarifications have been introduced.

It is proposed to set the development goals of the energy supplying companies as a change in the values of a set of key efficiency indicators, such as KPI (key performance indicators) [49]. The most well-known recommendations for using key performance indicators in the enterprise management are shown in the research [50], where it is proposed to apply the principle of $10 / 80 / 10$. This principle implies that 80 indicators for management should be production, 10 should reflect the enterprise's efficiency and another 10 show the enterprise's effectiveness. In this approach, the impact is the degree of achieving planned results and efficiency, i.e., the ratio between results achieved and resources spent on it.

Many contractors (actors) do not usually focus on the project's objectives; they just focus on their income or profits of the company [51]. The project depends on the executive's 
attitude from the start to the finish. The executive's attitude is very difficult to measure and to determine. However, if the contractor's attitude is known, the contractor's focus on the project objectives can be perceived [52].

R. Dutmer [52] confirmed that there is a significant profit from knowing relations of executives and contractors, but there is a lack of relevant research of a method to measure attitudes towards executives. Therefore, the first results of the research propose the models to identify and analyze the factors that influence the change in contractors' behavior based on the combination of expert methods and correlation and regression analysis. These models are descriptive and can be used for simulating contractors' behavior under different circumstances and depending on various influences.

The stages of the factor-reflexive approach to diagnosing the executives' and contractors' attitude to reaching the energy supplying companies' objectives that provide the opportunity to consider the behavior of contractors and employees of the company in terms of the system-reflexive approach comprise:

- Identifying the factors that influence the change in the counterparties' behavior;

- Determining the factors that influence the behavior of unplanned workers;

- Analyzing the impact of deviations from forecasts on deviations from plans.

To ensure implementation of these processes, the company has developed an appropriate set of economic and mathematical models that allow formalizing control over the company's development.

The model identifies factors influencing the contractors' behavior change based on the analysis of relations between the state and the actual performance of the energy supplying company, under which its contractors may change their strategy between indicators of the contractors' strategy to those of the enterprise.

Model factors influencing the strategy of the contractor to the enterprise, in general, can be presented as:

$$
a_{i}=f_{i}\left(W_{i}, B_{i}, E_{i}\right)
$$

where $W_{i}$ is a set of the enterprise indicators that affect the $i$-th aspect of the contractors' strategy in relation to the enterprise; $B_{i}$ is a set of internal factors of the contractors, influencing $i$-th aspect of the contractors' strategy and the companies are unknown; $E_{i}$ is a set of external factors that affect $i$-th aspect of the contractors' strategy, and are well known.

Indicators that characterize a particular strategy and are formed under its influence depend on its individual aspects and the impact of the strategy implementation environment:

$$
I_{j}=g_{j}\left(A_{j}, E_{j}\right)
$$

where $A_{j}$ is a set of components of the contractors' strategy, defined by Equation (1) and affecting $j$-th indicator and $E_{j}$ is a set of external factors affecting $j$-th indicator indicative and are well-known.

Assuming that the impact of each factor is independent, the relation among indicators of strategy change and factors of strategy change is the sum of the influences of each group of factors.

$$
\Delta I=K_{w} \times F_{w}(\Delta W)+K_{e} \times F_{e}(\Delta E)+B
$$

where $\Delta W$ is a vector of changes at the enterprise; $\Delta E$ is a vector of changes in the state of the environment; $F_{w}(\Delta W)$ is a vector impact of changes at the enterprise; $F_{e}(\Delta E)$ is a vector impact of changes in the state of the environment; $K_{w}$ and $K_{e}$ are matrix weight ratios and the impact of changes in the environment on indicators of change in the strategy and $B$ is a vector cumulative effect of internal factors contractors and other uncertain factors.

Assuming that the dependence of the strategy indicator on the factors' influence is linear to Equation (3) it will take the form:

$$
\Delta I=K_{w} \times \Delta W+K_{e} \times \Delta E+B
$$


The sequence of constructing the identification models of dependences includes the following steps:

- Compiling the list of indicators of the power supplying enterprise's condition and activity influencing the contractors' strategy;

- Making the list of indicators characterizing the strategy of relations between contractors and the enterprise;

- Determining the impact of other factors on changing the strategy of the counterparty;

- Identifying the possible influence of changing factors on the change of indicators.

- Controlling the changes in the contractors' strategy involves the following stages:

- Making the list of indicators, the values of which differ from those forecasted;

- Analyzing the steam parameters for the correlation between the model and specification changes strategy contractors.

The practical implementation of the approach to the indicators that affect the formation of the contractors' strategy in cooperation with the enterprise includes, in particular, the following groups of factors:

- Financial: financial condition and solvency and bankruptcy risk. These factors are quite fully reflected in the indicators calculated according to the enterprise's financial statements;

- Marketing: pricing policy, market position and business reputation. Comparative analysis or expert evaluations can be used to determine such indicators;

- Information and communication: availability of information about the enterprise, the scope of communications with the counterparty, the stability of communication channels [53];

- Production: production volume stability, availability of capacity reserves and quality of services.

Social, economic, political and technological factors can be considered external factors [54].

The set of indicators that affect the behavior of the counterparty and their weight depends on the nature of the relation (supplier or buyer), the scope of the relation, the duration of the interaction and so on. Additionally, in addition to these indicators, the behavior of the counterparty in interaction with the company is affected by changes in the environment and internal factors of the counterparty.

Consumer ratios, a share of long-term contracts, settlement discipline, etc., can be considered as indicators of buyers' relations. Indicators of the supplier's strategy are the price level, the share of long-term contracts and credit policy.

The model for determining the influence of the strategy change factors on altering the strategy change indicator can be presented in the form of:

$$
\Delta I_{S}=\sum_{b=1}^{B} k_{b} \Delta w_{b}+\sum_{d=1}^{D} k_{d} \Delta e_{d}+C
$$

where $\Delta I_{s}$ is a relative change of strategy indicator; $\Delta w_{b}$ is a relative normalized change of the $b$-th indicator of the enterprise, which affects the strategy; $\Delta e_{d}$ is a relative normalized change in the d-rate of the environment that affects the strategy; $k_{b}$ and $k_{d}$ are weight changes and environmental impacts and $C$ is a cumulative effect of internal factors contractors and other uncertain factors.

The model assumes the replacement of a weighted sum of environmental factors in the second product by a weighted complex indicator that sufficiently characterizes the state of the environment from the standpoint of determining the indicator. The initial set of indicators and their share are determined by expert evaluation. Adjustment of the model in the control process means changing the weight coefficients to ensure compliance of the forecast and actual value of indicators at a minimum value of $C$, or to minimize the discrepancy between the forecast and actual value of the indicator with a limited relative value of $\mathrm{C}$. In some cases, in order to adjust the model for determining the nonlinear nature 
of the indicator's dependence on the change of factors or the combined influence of factors, it is advisable to use the nonlinear function $\mathrm{kf}(\mathrm{wb})$. Thus, by comparing the correlation between the actual values of parameters and preliminary experts' estimates discrepancies can be identified and forecasting and planning models can be improved.

An important factor in the quality of enterprise development is the coherent state of management circuits consistency, which implies consistency of goals and resources over time. However, no less important is the assessment of such consistency from the standpoint of the employees who are the direct executives of tasks, which will ultimately affect the quality of tasks done [55]. Therefore, to determine the factors that affect employee behavior, it is necessary to assess the attitude of employees to the established plans for the units' development and to their implementation. It is possible to identify a number of the most common discrepancies that lead to gaps between management's expectations, which are reflected in development plans, and the actual results in their implementation. These include:

- A mismatch between the scale or the task complexity and the level of the doer, when at lower levels there are set the tasks of higher levels (for example, increase sales of the entire enterprise for individual executives at the level of production unit or planning unit or entrust a highly skilled employee to perform tasks of low complexity);

- An inconsistency between the tasks set and the resources available (production, personnel and financial);

- Errors of the management system in planning and implementing the development projects (distribution of processes, functions and resources, time management, communication management, employee motivation, etc.) [56].

To formalize these errors and minimize their potential impact at the planning stage, it is necessary to establish a link among the level of discrepancies, the employees' subjective assessment of these discrepancies and of their impact and the actual consequences.

In the second part of the study, a closed rating scale was established by summarizing expert opinions (middle managers and researchers) and clarified according to the previous survey. An anonymous survey was carried out in a mixed form (internally and remotely (Google Forms)), with internally inconsistent answers ignored and formal questions adapted to a specific activity. During the main survey at 5 enterprises (energy field), there were received 1152 valid responses ( $91 \%$ of the total) that characterize 136 production tasks. To confirm the hypothesis of a dependency package, SPSS was used with the model parameters altered.

\section{Results}

Detection of inconsistencies' influence on the behavior of employees is determined by a survey. The questionnaire is based on three groups of questions (1) compliance with the doer's level; (2) compliance with resources and (3) the quality of management), which provide information about the employees' subjective attitude to the tasks.

To assess the team's opinion on the adequacy of the tasks set, it is proposed to calculate the assessment as weighted, taking into account the impact of deviations as normalized count from 0 to 1 maximum deviation:

$$
M_{z}=\frac{\sum_{w}\left(1-\frac{\left(m^{\text {MaxSum }}-m_{z, b}^{\text {lev }}-m_{z, b}^{r e s}-m_{z, b}^{m a n}\right)}{m^{\text {MaxSum }}}\right)}{B_{z}},
$$

where $M_{Z}$ is the team's assessment of the quality of $z$-th set task; $m_{z, b}^{\text {lev }}$ is the assessment by $b$-th employee of compliance with the level of the doer $z$-th task; $m_{z, b}^{r b s}$ is the assessment by $b$-th employee of the $z$-th task's compliance with available resources; $m_{z, b}^{\operatorname{man}}$ is the assessment by $b$-th employee of the management quality while executing $z$-th task; $m^{\text {MaxSum }}$ is the 
tasks' maximum possible negative assessment; $B_{z}$ is the number of employees involved in $z$-th task and $Z$ is the number of tasks that have been set to achieve development goals.

Additionally, an important factor that determines the impact of discrepancies on the degree of task implementation is the subjective assessment of the relation between the level of deviation and the level of deviation's impact on the task. It is proposed to identify five levels of impact for evaluation (Table 1).

Table 1. A scale for evaluating the impact of inconsistencies on the task.

\begin{tabular}{lc}
\multicolumn{1}{c}{ Level of Influence } & Rating \\
\hline The task is not affected & 0 \\
\hline The task is possible with extra effort & 1 \\
\hline There is a slight deviation from the plan & 2 \\
\hline There is a significant deviation from the plan & 3 \\
\hline The task execution is impossible & 4 \\
\hline
\end{tabular}

The non-conformities impact on the employees' behavior was studied by means of a questionnaire, which determines the employees' attitude to the tasks and subjective evaluation of certain discrepancies' impact on the final result. The depersonalized results of the questionnaire and the generalized result are shown in Figure 1.

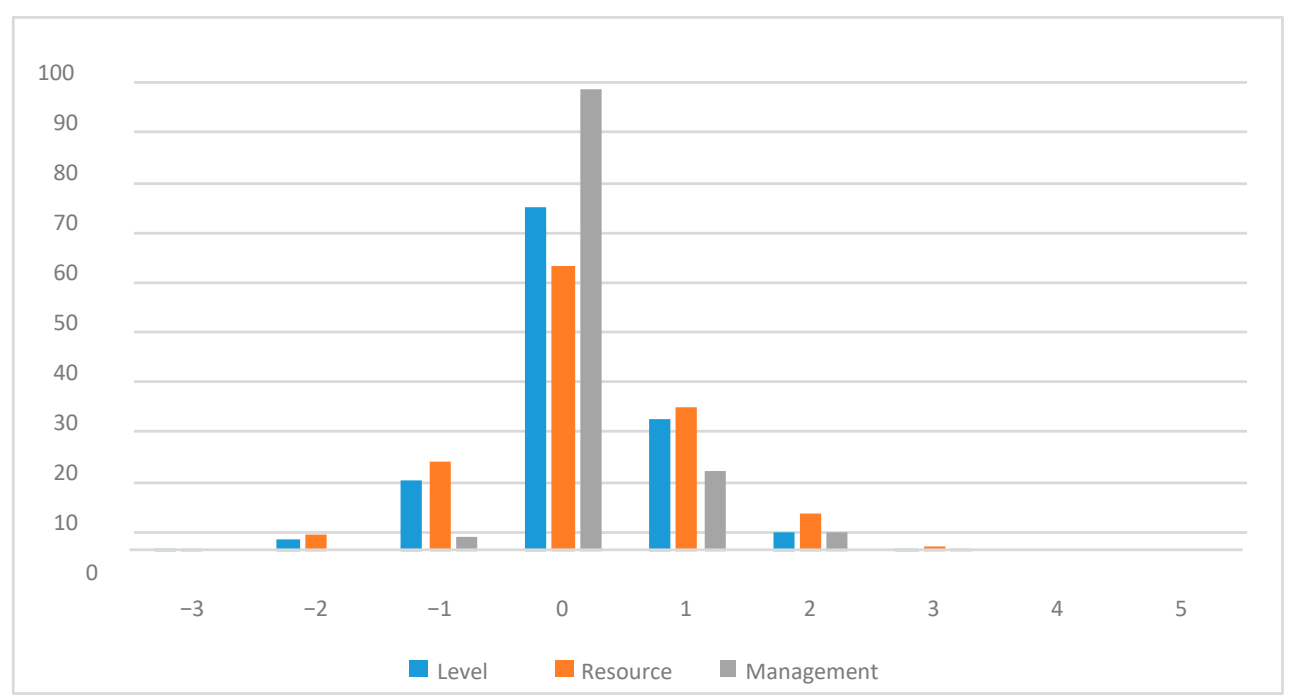

Figure 1. General evaluation of discrepancies by the enterprises' employees.

The generalized results of the subjective evaluation of the deviations impact on the final result are shown in Figure 2.

The results of the survey provide an opportunity to address two issues. First, it is possible to determine whether workers consider the tasks adequate. Depending on this, conclusions can be drawn about the presence of hidden resistance and opportunistic behavior. The second question is the degree of unanimity in the workers' attitude to the tasks. 

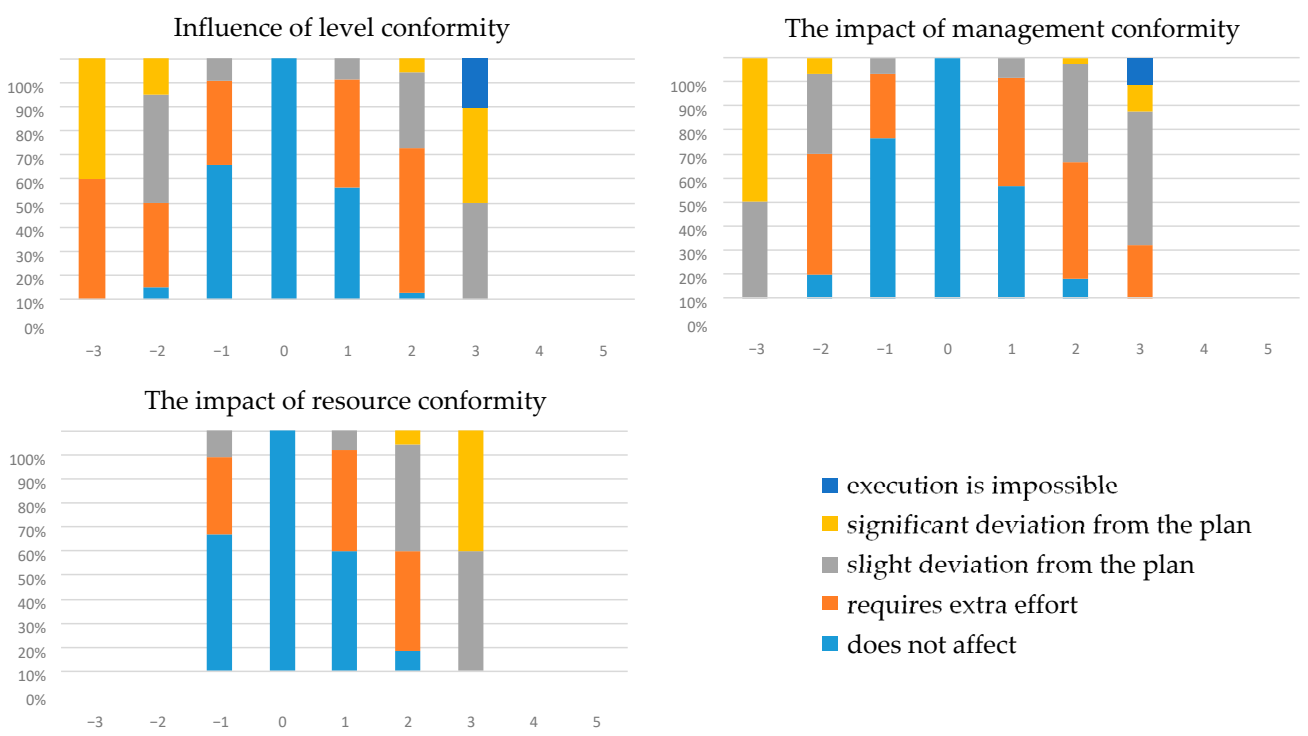

- execution is impossible

significant deviation from the plan

slight deviation from the plan

requires extra effort

- does not affect

Figure 2. Generalized evaluation of the discrepancies' impact on the task.

To evaluate the team's opinion on the adequacy of the tasks, it is proposed to calculate the assessment as weighted, taking into account the impact of deviations from the maximum value:

$$
\begin{gathered}
C_{z, k}=\frac{\sum_{i=1}^{N_{z}}\left|s_{z, k, i}\right|^{\alpha}}{N_{z}} \\
C_{z}=\sqrt{C_{z, L}+C_{z, R}+C_{z, M}} \\
z=1 \ldots Z
\end{gathered}
$$

where $C_{z}$ is general evaluation of conformity by the $z$-th set task doers; $C_{z, k}$ is evaluation of conformity by $z$-th set task doers for a separate $k$-th component $(L$-level, $R$-resources and $M$-management); $s_{z, k, i}$ is evaluation of $z$-th task conformity by $i$-th doer on $k$-th component; $N_{z}$ is the number of doers who gave a conformity evaluation of $z$-th task and $Z$ is the number of tasks in the analysis of conformity.

An indicator $\alpha$ characterizes the dependence of the expected consequences of deviation from the level of inconsistency, taking into account the type of tasks and characteristics of the enterprise, and can be determined by expert evaluation or retrospective analysis of the results of tasks, and further clarified by accumulating sufficient statistical information. When $\alpha=2$ as the limit, above which the influence of the established discrepancies can be considered significant, it is possible to accept the value $C_{z, k}>1$ for a separate component of conformity and $C_{z}>1.72$ for the general evaluation of the task conformity.

The conformity of employees' evaluations of the availability and degree of nonconformity characterizes the personnel policy of the enterprise, management style and internal unity of the team. Additionally, coherence makes it possible to assess the level of doers' reflection in relation to the tasks and the ability of employees to coordinate via communication [56,57].

To assess the degree of employees' unanimity about the established tasks, it was proposed to calculate the unadjusted standard deviation of the doers' estimates on the scale from Table 2:

$$
\begin{gathered}
D_{z}=\sqrt{\mathrm{D}_{\mathrm{z}, \mathrm{L}}^{2}+\mathrm{D}_{\mathrm{z}, \mathrm{R}}^{2}+\mathrm{D}_{\mathrm{z}, \mathrm{M}}^{2}} \\
\mathrm{D}_{\mathrm{z}, \mathrm{k}}=\sqrt{\frac{\sum_{\mathrm{i}=1}^{\mathrm{N}_{\mathrm{z}}}\left(\mathrm{s}_{\mathrm{z}, \mathrm{k}, \mathrm{i}}-\overline{\mathrm{s}}_{\mathrm{z}, \mathrm{k}}\right)}{\mathrm{N}_{\mathrm{z}}}} \\
\overline{\mathrm{s}}_{\mathrm{z}, \mathrm{k}}=\frac{\sum_{\mathrm{i}=1}^{\mathrm{N}_{\mathrm{z}}} \mathrm{s}_{\mathrm{z}, \mathrm{k}, \mathrm{i}}}{\mathrm{N}_{\mathrm{z}}}
\end{gathered}
$$


where $D_{z}$ is a general inconsistency of evaluations by the team of $z$-the set task; $D_{z, k}$ is an inconsistency of the team's evaluations of conformity with $z$-th set task for $k$-th component and $\mathrm{s}_{\mathrm{z}, \mathrm{k}}$ is the average score of $z$-th task for $k$-th component.

Table 2. A Scale for assessing the employees' subjective attitude to the tasks.

\begin{tabular}{|c|c|c|c|}
\hline $\begin{array}{c}\text { Matching the Doer's Level of } \\
\text { Aptitude }\end{array}$ & Resource Compliance & Management Quality & Rating \\
\hline $\begin{array}{l}\text { Must be executed at three or more } \\
\text { levels of the hierarchy above }\end{array}$ & $\begin{array}{l}\text { A catastrophic lack of } \\
\text { resources to implement }\end{array}$ & $\begin{array}{l}\text { The process is carried out with no } \\
\text { interference by the subject of } \\
\text { management (is unmanageable) }\end{array}$ & 5 \\
\hline $\begin{array}{l}\text { Must be performed at two levels of } \\
\text { the hierarchy above }\end{array}$ & $\begin{array}{l}\text { A significant lack of resources } \\
\text { to complete the task }\end{array}$ & $\begin{array}{l}\text { There are significant shortcomings in } \\
\text { management }\end{array}$ & 4 \\
\hline $\begin{array}{l}\text { Must be done at one hierarchical } \\
\text { level higher }\end{array}$ & $\begin{array}{l}\text { An essential lack of resources } \\
\text { to implement }\end{array}$ & $\begin{array}{c}\text { There are essential shortcomings in } \\
\text { management }\end{array}$ & 3 \\
\hline $\begin{array}{c}\text { Must be performed at the same } \\
\text { level by a highly qualified } \\
\text { employee }\end{array}$ & $\begin{array}{l}\text { A noticeable lack of resources } \\
\text { to implement }\end{array}$ & $\begin{array}{c}\text { There are noticeable shortcomings in } \\
\text { management }\end{array}$ & 2 \\
\hline $\begin{array}{c}\text { Must be performed at the same } \\
\text { level by other doers with similar } \\
\text { qualifications }\end{array}$ & $\begin{array}{l}\text { A slight lack of resources to } \\
\text { implement }\end{array}$ & $\begin{array}{l}\text { There are minor shortcomings in } \\
\text { management }\end{array}$ & 1 \\
\hline $\begin{array}{c}\text { Corresponds to the doer's level and } \\
\text { qualifications }\end{array}$ & $\begin{array}{c}\text { Enough resources to complete } \\
\text { the task }\end{array}$ & Completely satisfactory & 0 \\
\hline $\begin{array}{l}\text { Must be done at the same level by a } \\
\text { lower qualified worker }\end{array}$ & $\begin{array}{l}\text { A slight excess of resources to } \\
\text { do the task }\end{array}$ & $\begin{array}{l}\text { External managerial influence is } \\
\text { excessive }\end{array}$ & -1 \\
\hline $\begin{array}{l}\text { Must be done at one level of the } \\
\text { hierarchy below }\end{array}$ & $\begin{array}{l}\text { An essential excess of } \\
\text { resources }\end{array}$ & $\begin{array}{l}\text { External managerial influence } \\
\text { interferes with normal activities }\end{array}$ & -2 \\
\hline $\begin{array}{l}\text { Must be done at two or more levels } \\
\text { of the hierarchy below }\end{array}$ & $\begin{array}{l}\text { A significant surplus of } \\
\text { resources to perform }\end{array}$ & $\begin{array}{l}\text { External managerial influence hinders } \\
\text { normal activities }\end{array}$ & -3 \\
\hline
\end{tabular}

Extended and supplemented by the authors based on [29,55].

If the total inconsistency exceeds the threshold $D_{z}>1$, it should be determined what causes the nonconformity-general inconsistency in views or significant contradictions in evaluating a particular component of the assessment. Additionally, conformity with the doer's level, resources and quality of management, for which the limit of consistency is recommended to be $\mathrm{D}_{\mathrm{z}, \mathrm{k}}>0.5$.

Summarizing the results of the employees' survey on the tasks' conformity, according to the components and criteria from Table 1, the total number of processed tasks 136 are shown in Table 3 and the consistency of the obtained estimates are shown in Table 4.

Table 3. Assessment of conformity with tasks.

\begin{tabular}{|c|c|c|c|c|}
\hline Non Conformity & \multicolumn{4}{|c|}{ Number of Tasks } \\
\hline equal & 50 & \multirow{2}{*}{44} & - & \multirow{3}{*}{23} \\
\hline resources & 74 & & \multirow{2}{*}{25} & \\
\hline management & 26 & - & & \\
\hline conformity & \multicolumn{3}{|c|}{56} & \\
\hline
\end{tabular}


Table 4. Consistency of task conformity evaluations.

\begin{tabular}{|c|c|c|c|c|}
\hline Inconsistency & \multicolumn{4}{|c|}{ Number of Tasks } \\
\hline equal & 33 & \multirow{2}{*}{27} & - & \multirow{3}{*}{7} \\
\hline resources & 36 & & \multirow{2}{*}{13} & \\
\hline management & 15 & - & & \\
\hline consistency & \multicolumn{3}{|c|}{93} & \\
\hline
\end{tabular}

The obtained results indicate a significant degree of the respondents' negative evaluation of the tasks compliance. Thus, less than a half of the evaluated tasks are fully conforming. Most inconsistencies are recognized in evaluating the adequacy of resource provision and the least are about the adequacy of management provision. The main discrepancies in the level recognized by the respondents include the performance of simple tasks by qualified personnel and the suboptimal, in their opinion, distribution of tasks among doers. Respondents indicate a slight and noticeable lack of resources or a slight excess of them. However, doers indicate that over $90 \%$ of the recognized inconsistencies will not affect the assignment or would only increase efforts at implementation without affecting the end result. Accordingly, the identified inconsistencies do not require a prompt response, but rather characterize the overall level of employee dissatisfaction with the organization of work and indicate the availability of additional reserves to improve the efficiency of tasks implementation.

The analysis of the answers' agreement showed that the level of inconsistency increases with the growth of the general evaluation of the task's inconsistency, which confirms the calculation of the correlation coefficients between the assessments of discrepancy and inconsistency summarized in Table 5.

Table 5. The link between the tasks mismatch and the answers' inconsistency.

\begin{tabular}{cc}
\hline Indicator & Correlation Coefficient \\
\hline Level & 0.71 \\
\hline Resources & 0.61 \\
\hline Management & 0.73 \\
\hline Overall rating & 0.73 \\
\hline
\end{tabular}

The results grouped according to the enterprises studied are shown in Tables 6 and 7 .

Table 6. Evaluation of the tasks conformity at enterprises.

\begin{tabular}{cccccc}
\hline \multirow{2}{*}{$\begin{array}{c}\text { Company } \\
\text { Code }\end{array}$} & $\begin{array}{c}\text { Number of } \\
\text { Tasks }\end{array}$ & \multicolumn{3}{c}{ Non Conformity } & Conformity \\
\cline { 3 - 5 } & 27 & $37 \%$ & $44 \%$ & $22 \%$ & $48 \%$ \\
\hline 1 & 13 & $15 \%$ & $38 \%$ & $15 \%$ & $54 \%$ \\
\hline 2 & 50 & $0 \%$ & $4 \%$ & $2 \%$ & $94 \%$ \\
\hline 3 & 29 & $24 \%$ & $28 \%$ & $14 \%$ & $72 \%$ \\
\hline 4 & 17 & $35 \%$ & $41 \%$ & $6 \%$ & $53 \%$ \\
\hline 5 & & & & & Resources \\
\hline
\end{tabular}


Table 7. Consistency of tasks conformity evaluation at enterprises.

\begin{tabular}{cccccc}
\hline \multirow{2}{*}{$\begin{array}{c}\text { Company } \\
\text { Code }\end{array}$} & $\begin{array}{c}\text { Number of } \\
\text { Tasks }\end{array}$ & Level & Resources & Management & Conformity \\
\cline { 3 - 5 } & 27 & $41 \%$ & $37 \%$ & $19 \%$ & $56 \%$ \\
\hline 1 & 13 & $31 \%$ & $62 \%$ & $31 \%$ & $31 \%$ \\
\hline 2 & 50 & $8 \%$ & $12 \%$ & $4 \%$ & $88 \%$ \\
\hline 3 & 29 & $21 \%$ & $21 \%$ & $10 \%$ & $72 \%$ \\
\hline 4 & 17 & $47 \%$ & $35 \%$ & $6 \%$ & $53 \%$ \\
\hline 5 & & & & & \\
\hline
\end{tabular}

The results of the non-conformity evaluation can characterize the company to some extent. Employees' negative reactions to the tasks received prove the existence of certain personnel, organizational and communication problems. The psychological climate in the team and the system of corporate values also have an impact on the evaluation results.

For enterprise 4 , and especially for enterprise 3 , a sufficient level of consistency can be noted; for enterprises 2 and 5 this level is insufficient and needs reacting. For enterprise 2, the first thing to pay attention to is the high level of inconsistency.

An increase in the level of inconsistency reduces the reliability of the non-compliance evaluation. For the tasks with a very high level of non-compliance, the problem of selecting doers should be considered, not the problem of proper provision. The high level of inconsistency for the task, especially a steady trend towards its growth available, can be considered as an indicator of management inefficiency and employee dissatisfaction to be used in the model of diagnosis and crisis phenomena [58].

\section{Discussion}

This article outlines the models to identify and analyze the factors that influence the change in the contractors' behavior, based on the combination of methods and expert estimates. Correlation and regression analysis is a process and predicts the contractor's behavior based on reflective effects. These models are descriptive and can be used for simulating the contractor's behavior at the enterprises of energy supplying companies in different circumstances and depending on various influences.

The results of the first part of the research demonstrate the effectiveness of the proposed factor-reflexive approach to diagnosing the contractors' response and existing implementation of the tasks and the resulting changes and match simulation experiment, which uses behavior, which is not optimal at the initial time.

The model factors determine the impact of changes in the strategy on shifting indicator changes strategy, which involves the replacement of a weighted sum of external environment factors, complex weighted index that characterizes the state of the environment rather than determining a position indicator.

The initial set of indicators and their share are determined by expert evaluation. Adjustment of the model in the control process means changing the weight coefficients to ensure compliance of the forecast and actual value of indicators at a minimum value of the cumulative impact of internal counterparty factors and other uncertain factors $(C$ in formula 5), or to minimize the discrepancy between the forecast and actual value of the indicator with a limited relative value of the cumulative impact of the counterparty's internal factors and other uncertain factors ( $C$ in formula 5$)$. In some cases, in order to adjust the model for determining the nonlinear nature of the indicator's dependence on the change of factors or the combined influence of factors, it is advisable to use the nonlinear function of the normalized change in the selected enterprise indicator that affects the strategy $(k f(w b)$ in formula 5).

Thus, by comparing the correlation between the actual values of parameters and preliminary experts' estimates discrepancies can be identified and forecasting and planning models can be improved. 
Comparing the results of our simulation experiments with those obtained by other authors [22-26] led to the conclusion about the acceptability of the approach outlined in the article.

The impact of discrepancies on the employees' behavior is determined by means of a questionnaire, which shows the employees' attitude at energy supplying companies to the tasks and subjective evaluation of the impact of certain discrepancies on the final result.

The generalized results shown in the graphs in Figures 1 and 2 provide answers regarding the availability of hidden resistance and opportunistic behavior and the degree of consensus with respect to the workers of energy supplying companies who are assigned the tasks. A closed scale evaluation was made by summarizing expert opinions and refined according to the previous survey.

At this stage, the main survey comprised a fairly small number of companies (five companies of the energy sector, which received 1152 valid responses that characterize the 136 production problems) because the research focused on the energy sector. This fact put the current stage of work at a certain disadvantage in the framework of ongoing research.

Cognitive technologies for the transfer of knowledge by using artificial intelligence will produce the ability to create a competitive software diagnostics attitude of doers and contractors to achieve the development objectives based on the factor-reflexive approach that we see as the future prospect for our research.

\section{Conclusions}

Descriptive models have been developed to identify and analyze the factors that influenced the change of contractors' behavior: the influence of factors on the contractors' strategy in relation to the enterprise and determination of the influence factors change strategy to replace the indicator change strategy. The model assumes the replacement of the weighted sum of environmental factors in the second product by a weighted complex indicator that sufficiently characterizes the state of the environment from the standpoint of determining the indicator.

Proposed models can be used to simulate the contractors' behavior in various circumstances and depending on various influences.

To reflect the subjective evaluation of the staff level variations in the tasks set there is proposed a closed assessment scale that was set by summarizing expert opinion and adjustment according to the previous survey. The anonymous survey was conducted in a mixed form, internally nonconforming answers were ignored and formalized questions were adapted to the specificity of the enterprises. The obtained results indicate a significant degree of the respondents' negative evaluation of the tasks compliance.

Thus, less than a half of the evaluated tasks are fully conforming. Most inconsistencies are recognized in evaluating the adequacy of resource provision and the least are about software control. The main discrepancies in the level recognized by the respondents include the performance of simple tasks by qualified personnel and the suboptimal, in their opinion, distribution of tasks among doers. Respondents indicate a slight and noticeable lack of resources or a slight surplus of them. However, doers indicate that over $90 \%$ of the recognized inconsistencies will not affect the task or would only increase efforts of its implementation without affecting the end result. Accordingly, the identified inconsistencies do not require a prompt response, but rather characterize the overall level of employee dissatisfaction with the labor organization and indicate the availability of additional reserves to improve the efficiency of tasks implementation.

Summing up, this study demonstrates that the high level of the non-conformity problem and its stable trend to the growth suggest their being viewed as an indicator of ineffective management and their being used in a staff dissatisfaction model for diagnosis and crisis.

The factor-reflexive approach to diagnosing the doers' and contractors' response to implementing the tasks and the resulting changes is applied taking into account the subjective component of their response, which makes it possible to control the evaluation of 
deviations and the corresponding adaptation. Practical implementation of this approach in monitoring the conformity of development tasks has proven the ability to identify problems from the viewpoint of the task doers.

The findings of this study suggest that practical implementation of conformity control of the development tasks has proven the capacity to identify bottlenecks from the viewpoint of the task doers and also indirectly assess the employees' generalized viewpoint on organization, resource and staffing of the development projects. This takes into account that deviations may be due to external and internal influences. Considering the sources of deviations from the plans requires using a systematic approach, and the possibility of deviations due to the counterparties' response to the plans of the enterprise calls for applying a reflective approach.

Thus, the use of factor-reflexive approach to diagnosing the reaction of executives and contractors to the tasks and consequences of changes in the activities of energy service companies, allowed removing restrictive barriers (distrust from the (potential) customer, obtaining clear information and awareness of executives and contractors and their low communication experience), which hinder the development of the EU energy services market.

Further development of the proposed approach to evaluating contractors' response will be to adjust and expand models with diagnostics accumulating sufficient statistical data allowing for the relations and the environment of the energy supplying company. Expanding and improving the quality of the problems' diagnosis in terms of evaluating and responding to challenges of the doers and groups needs clarifying the degree of influence by inconsistencies and boundary conditions.

In addition, the factor-reflexive approach presented in the article can be integrated into already existing models of economic sustainability [3,8-10,14,15,19,23,24,59-73], and can also be used to form and adjust strategies of various scales and areas of management.

Author Contributions: Conceptualization, A.K. (Aleksandra Kuzior), A.K. (Aleksy Kwilinski), and I.H.; methodology, A.K. (Aleksandra Kuzior), A.K. (Aleksy Kwilinski), and I.H.; software, A.K. (Aleksandra Kuzior), A.K. (Aleksy Kwilinski), and I.H.; validation, A.K. (Aleksandra Kuzior), A.K. (Aleksy Kwilinski), and I.H.; formal analysis, A.K. (Aleksandra Kuzior), A.K. (Aleksy Kwilinski), and I.H.; investigation, A.K. (Aleksandra Kuzior), A.K. (Aleksy Kwilinski), and I.H.; resources, A.K. (Aleksandra Kuzior), A.K. (Aleksy Kwilinski), and I.H.; data curation, A.K. (Aleksandra Kuzior), A.K. (Aleksy Kwilinski), and I.H.; writing-original draft preparation, A.K. (Aleksandra Kuzior), A.K. (Aleksy Kwilinski), and I.H.; writing-review and editing, A.K. (Aleksandra Kuzior), A.K. (Aleksy Kwilinski), and I.H.; visualization, A.K. (Aleksandra Kuzior), A.K. (Aleksy Kwilinski), and I.H.; supervision, A.K. (Aleksandra Kuzior), A.K. (Aleksy Kwilinski), and I.H.; project administration, A.K. (Aleksandra Kuzior), A.K. (Aleksy Kwilinski), and I.H.; funding acquisition, A.K. (Aleksandra Kuzior), A.K. (Aleksy Kwilinski), and I.H. All authors have read and agreed to the published version of the manuscript.

Funding: The research received funding under the research subsidy of the Faculty of Organization and Management of the Silesian University of Technology for the year 2021 (13/990/BK21/0163).

Institutional Review Board Statement: Not applicable.

Informed Consent Statement: Not applicable.

Data Availability Statement: Not applicable.

Acknowledgments: The authors are very grateful to the anonymous referees for their helpful comments and constructive suggestions.

Conflicts of Interest: The authors declare no conflict of interest. 


\section{References}

1. Bertoldi, P.; Boza-Kiss, B.; Toleikyté, A. Energy Service Market in the EU; Publications Office of the European Union: Luxembourg, 2019. [CrossRef]

2. Talon, C.; Gartner, J. Energy Service Company Market Overview Expanding ESCO Opportunitiesin the United States and Europe: Executive Summary; Navigant Consulting: Boulder, CO, USA, 2015.

3. Pratten, S. Economics as Progress: The LSE Approach to Econometric Modelling and Critical Realism as Programmes for Research. Cam. J. Econ. 2005, 29, 179-205. [CrossRef]

4. Patomäki, H. What Next? An Explanation of the 2008-2009 Slump and Two Scenarios of the Shape of Things to Come. Globalizations 2010, 7, 67-84. [CrossRef]

5. Patomäki, H. Capitalism: Competition, Conflict, Crisis. J. Crit. Realism 2003, 1, 173-179. [CrossRef]

6. Minton, N. Cognitive Biases and Reflexive Control; The Open University and Jisc: Oxford, UK, 2017.

7. Rennison, B.W. Reflexive Management: System-Theoretical Reflection on Reflection. J. Lead. Manag. 2015, 1, 27-36.

8. Paroutis, S.; Bennett, M.; Heracleous, L. A Strategic View on Smart City Technology: The Case of IBM Smarter Cities during a Recession. Technol. Forecast. Soc. Chang. 2014, 89, 262-272. [CrossRef]

9. Hollands, R.G. Critical Interventions into the Corporate Smart City. Camb. J. Reg. Econ. Soc. 2015, 8, 61-77. [CrossRef]

10. Angelidou, M. Smart City Policies: A Spatial Approach. Cities 2014, 41, 3-11. [CrossRef]

11. Irani, Z.; Sharif, A.; Kamal, M.M.; Love, P.E. Visualizing a Knowledge Mapping of Information Systems Investment Evaluation. Expert Syst. Appl. 2014, 41, 105-125. [CrossRef]

12. Gottschlich, J.; Hinz, O.A. Decision Support System for Stock Investment Recommendations Using Collective Wisdom. Decis. Support Syst. 2014, 59, 52-62. [CrossRef]

13. Strantzali, E.; Aravossis, K. Decision Making in Renewable Energy Investments: A Review. Renew. Sustain. Energy Rev. 2016, 55, 885-898. [CrossRef]

14. Lakhno, V.; Malyukov, V.; Bochulia, T.; Hipters, Z.; Kwilinski, A.; Tomashevska, O. Model of Managing of the Procedure of Mutual Financial Investing in Information Technologies and Smart City Systems. Int. J. Civil Eng. Technol. 2018, 9, $1802-1812$.

15. Kuzior, A.; Kuzior, P. The Quadruple Helix Model as a Smart City Design Principle. Virtual Econ. 2020, 3, 39-57. [CrossRef]

16. Miśkiewicz, R. Challenges Facing Management Practice in the Light of Industry 4.0: The Example of Poland. Virtual Econ. 2019, 2, 37-47. [CrossRef]

17. Miśkiewicz, R.; Wolniak, R. Practical Application of the Industry 4.0 Concept in a Steel Company. Sustainability 2020, $12,5776$. [CrossRef]

18. Altuntas, S.; Dereli, T. A Novel Approach Based on DEMATEL Method and Patent Citation Analysis for Prioritizing a Portfolio of Investment Projects. Expert Syst. Appl. 2015, 42, 1003-1012. [CrossRef]

19. Kwilinski, A.; Tkachenko, V.; Kuzior, A. Transparent Cognitive Technologies to Ensure Sustainable Society Development. J. Secur. Sustain. Issues 2019, 9, 561-570. [CrossRef]

20. Kwilinski, A.; Kuzior, A. Cognitive Technologies in the Management and Formation of Directions of the Priority Development of Industrial Enterprises. Manag. Syst. Prod. Eng. 2020, 28, 119-123. [CrossRef]

21. Kuzior, A. Development of Competences Key to Sustainable Development. Zesz. Nauk. Organ. Zarzadzanie 2014, $75,71-81$.

22. Kuzior, A.; Kwilinski, A.; Tkachenko, V. Sustainable Development of Organizations Based on the Combinatorial Model of Artificial Intelligence. Entrep. Sustain. 2019, 7, 1353-1376. [CrossRef]

23. Dalevska, N.; Khobta, V.; Kwilinski, A.; Kravchenko, S. A Model for Estimating Social and Economic Indicators of Sustainable Development. Entrep. Sustain. Issues 2019, 6, 1839-1860. [CrossRef]

24. Kuzior, A. The ICT as a Tool for Sustainable Development. In Contemporary Developmental Challenges; Kuzior, A., Ed.; Belianum Matej Bel University Press: Banska Bystrica, Slovak Republic, 2013; pp. 7-28.

25. Dźwigoł, H.; Shcherbak, S.; Semikina, M.; Vinichenko, O.; Vasiuta, V. Formation of Strategic Change Management System at an Enterprise. Acad. Strat. Manag. J. 2019, 18, 1-8.

26. Dzwigol, H.; Dzwigol-Barosz, M.; Kwilinski, A. Formation of Global Competitive Enterprise Environment Based on Industry 4.0 Concept. Int. J. Entrep. 2020, 24, 1-5.

27. Fobel, P.; Kuzior, A. The Future (Industry 4.0) is Closer than We Think. Will it also be Ethical? AIP Conf. Proc. 2019, $21,80-83$. [CrossRef]

28. Kumar, N.; Kumar, J. Efficiency 4.0 for Industry 4.0. Hum. Technol. 2019, 15, 55-78. [CrossRef]

29. MacKenzie, M.; Siu, L.; MacKenzie, D. An Engine, Not a Camera. Finance Theory and the Making of Markets; MIT Press: Cambridge, MA, USA, 2006.

30. MacKenzie, D.; Muniesa, F.; Siu, L. Do Economist Make Markets? On the Performativity of Economics; Princeton University Press: Princeton, NJ, USA, 2007.

31. Soros, G. Fallibility, Reflexivity, and the Human Uncertainty Principle. J. Econ. Methodol. 2013, 20, 309-329. [CrossRef]

32. Yan, T.; Ma, C. The BCR algorithms for solving the reflexive or anti-reflexive solutions of generalized coupled Sylvester matrix equations. J. Franklin Inst. 2020, 357, 12787-12807. [CrossRef]

33. Tubaro, P.; Ryan, L.; Casilli, A.A.; D'Angelo, A. Social network analysis: New ethical approaches through collective reflexivity. Introduction to the special issue of Social Networks. Soc. Netw. 2021, in press. [CrossRef] 
34. Robert, K.; Ola, L. Reflexive sensegiving: An open-ended process of influencing the sensemaking of others during organizational change. Eur. Manag. J. 2021, in press. [CrossRef]

35. McKeown, J.; Ladegaard, H.J. Exploring dominance-linked reflexive metadiscourse in moderated group discussions. J. Pragmat. 2020, 166, 15-27. [CrossRef]

36. Wang, L.; Jiang, W.; Zhang, H.; Lin, H. Leader information seeking, team performance and team innovation: Examining the roles of team reflexivity and cooperative outcome interdependence. Inf. Process. Manag. 2020, 57, 102343. [CrossRef]

37. Parsons, R.; Luke, H. Comparing reflexive and assertive approaches to social license and social impact assessment. Extr. Ind. Soc. 2021, in press. [CrossRef]

38. Igamberdiev, A.U.; Brenner, J.E. The evolutionary dynamics of social systems via reflexive transformation of external realit. Biosystems 2020, 197, 104219. [CrossRef] [PubMed]

39. Van der Biest, M.; Cracco, E.; Wisniewski, D.; Brass, M.; González-García, C. Investigating the effect of trustworthiness on instruction-based reflexivity. Acta Psychol. 2020, 207, 103085. [CrossRef]

40. Domínguez Benavides, T.; Japón, M.A. Fixed point properties and reflexivity in variable Lebesgue spaces. J. Funct. Anal. 2021, 280, 108896. [CrossRef]

41. Shadnam, M. Choosing whom to be: Theorizing the scene of moral reflexivity. J. Bus. Res. 2020, 110, 12-23. [CrossRef]

42. Paterson, C.; Chapman, J. Enhancing Skills of Critical Reflection to Evidence Learning in Professional Practice. Phys. Ther. Sport 2013, 14, 133-138. [CrossRef]

43. Bryant, R.L.; Wilson, G.A. Rethinking Environmental Management. Prog. Hum. Geogr. 1998, 22, 321-343. [CrossRef]

44. Bell, S.; Morse, S. Delivering Sustainability Therapy in Sustainable Development Projects. J. Environ. Manag. 2005, 75, 37-51. [CrossRef]

45. Schön, D.A. The Reflective Practitioner: How Professionals Think in Action; Basic Books: New York, NY, USA, 1983.

46. Bolton, G. Reflective Practice: Writing and Professional Development, 3rd ed.; Sage Publications: Thousand Oaks, CA, USA, 2010.

47. Loughran, J.; Cochran-Smith, M.; Lytle, S.; Loughran, J.J. Effective Reflective Practice: In Search of Meaning in Learning about Teaching. J. Teach. Educ. 2002, 53, 33-43. [CrossRef]

48. Newman, S. Constructing and Critiquing Reflective Practice. Educ. Action Res. 1999, 7, 145-163. [CrossRef]

49. Cambridge Dictionary. Available online: https://dictionary.cambridge.org/dictionary/english/kpi (accessed on 12 October 2020).

50. Parmenter, D. Key Performance Indicators: Developing, Implementing and Using Winning KPI's, 4th ed.; John Wiley \& Sons: Hoboken, NJ, USA, 2007.

51. Prichard, R. Contractor Qualification. 2000. Available online: https://www.irmi.com/articles/expert-commentary/contractorqualification (accessed on 12 October 2020).

52. Dutmer, R. Profit is an Attitude. 2002. Available online: http:/ /www.nationaldriller.com/CDA/ArticleInformation/features/ BNP_Features_Item/0,3643,75166,00.html (accessed on 12 October 2020).

53. Hroznyi, I.; Kuzmak, O.; Kuzmak, O.; Rusinova, O. Modeling Management of Diversification of Foreign Economic Interactions. Probl. Perspect. Manag. 2018, 16, 155-165. [CrossRef]

54. Hroznyi, I. Methods and Approaches to Quality Management of Industrial Enterprises. Bull. Odessa Natl. Univ. Ser. Econ. 2015, 20,75-79.

55. Zhovkovskaya, T. System-Reflexive Approach to Controlling the Development of an Industrial Enterprise. Black Sea Econ. Stud. 2018, 27, 123-129.

56. Bezchasnyi, O. Reflexive Coordination of Communications in the Construction of Models for the Development of an Industrial Enterprise. Virtual Econ. 2018, 1, 66-83. [CrossRef]

57. Bezchasnyi, O.; Khobta, V.; Pushak, Y.; Kotkalova-Litvin, I.; Dorovska, I. Modeling of Control of Stability of Communication Channels in Development Management Conditions. Financ. Credit Act. Probl. Theory Pract. 2018, 4, 282-295. [CrossRef]

58. Tarasova, H.; Zaharov, S.; Vereskun, M.; Kolosok, V. Preventive Anticrisis Strategy for Development of Industrial Enterprise. Ind. J. Manag. Prod. 2019, 10, 1405-1420. [CrossRef]

59. Kharazishvili, Y.; Kwilinski, A.; Sukhodolia, O.; Dzwigol, H.; Bobro, D.; Kotowicz, J. The Systemic Approach for Estimating and Strategizing Energy Security: The Case of Ukraine. Energies 2021, 14, 2126. [CrossRef]

60. Dzwigol, H. Meta-Analysis in Management and Quality Sciences. Market. Manag. Innov. 2021, 1, 324-335. [CrossRef]

61. Dzwigol, H.; Dzwigol-Barosz, M. Sustainable Development of the Company on the Basis of Expert Assessment of the Investment Strategy. Acad. Strat. Manag. J. 2020, 19, 1-7.

62. Lyulyov, O.; Pimonenko, T.; Kwilinski, A.; Dzwigol, H.; Dzwigol-Barosz, M.; Pavlyk, V.; Barosz, P. The Impact of the Gov-ernment Policy on the Energy Efficient Gap: The Evidence from Ukraine. Energies 2021, 14, 373. [CrossRef]

63. Kharazishvili, Y.; Kwilinski, A.; Grishnova, O.; Dzwigol, H. Social Safety of Society for Developing Countries to Meet Sus-tainable Development Standards: Indicators, Level, Strategic Benchmarks (with Calculations Based on the Case Study of Ukraine). Sustainability 2020, 12, 8953. [CrossRef]

64. Kuzior, A.; Lobanova, A. Tools of Information and Communication Technologies in Ecological Marketing under Conditions of Sustainable Development in Industrial Regions (Through Examples of Poland and Ukraine). J. Risk Financ. Manag. 2020, 13, 238. [CrossRef]

65. Czyżewski, B.; Matuszczak, A.; Polcyn, J.; Smędzik-Ambroży, K.; Staniszewski, J. Deadweight loss in environmental policy: The case of the European Union member states. J. Clean. Prod. 2020, 260, 121064. [CrossRef] 
66. Miskiewicz, R. Internet of Things in Marketing: Bibliometric Analysis. Market. Manag. Innov. 2020, 3, 371-381. [CrossRef]

67. Czyzewski, B.; Matuszczak, A.; Miśkiewicz, R. Public Goods Versus the Farm Price-Cost Squeeze: Shaping the Sustainability of the Eu's Common Agricultural Policy. Technol. Econ. Dev. Econ. 2019, 25, 82-101. [CrossRef]

68. Miśkiewicz, R. Efficiency of Electricity Production Technology from Post-Process Gas Heat: Ecological, Economic and Social Benefits. Energies 2020, 13, 6106. [CrossRef]

69. Lyulyov, O.; Pimonenko, T.; Stoyanets, N.; Letunovska, N. Sustainable Development of Agricultural Sector: Democratic Pro-file Impact Among Developing Countries. Res. World Econ. 2019, 10, 97. [CrossRef]

70. Dzwigol, H. Methodological and empirical platform of triangulation in strategic management. Acad. Strateg. Manag. J. 2020, 19, $1-8$.

71. Lyeonov, S.; Pimonenko, T.; Bilan, Y.; Štreimikienė, D.; Mentel, G. Assessment of Green Investments' Impact on Sustainable Development: Linking Gross Domestic Product Per Capita, Greenhouse Gas Emissions and Renewable Energy. Energies 2019, 12, 3891. [CrossRef]

72. Miśkiewicz, R. The Impact of Innovation and Information Technology on Greenhouse Gas Emissions: A Case of the Visegrád Countries. J. Risk Financ. Manag. 2021, 14, 59. [CrossRef]

73. Vasylieva, T.; Pavlyk, V.; Bilan, Y.; Mentel, G.; Rabe, M. Assessment of Energy Efficiency Gaps: The Case for Ukraine. Energies 2021, 14, 1323. [CrossRef] 